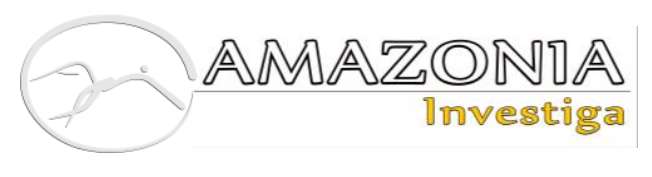

DOI: https://doi.org/10.34069/AI/2021.46.10.23

How to Cite:

Shkvorchenko, N., Hromovenko, V., \& Sharapanovska, Y. (2021). The concept of "pandemic" in modern English-language political discourse. Amazonia Investiga, 10(46), 225-233. https://doi.org/10.34069/AI/2021.46.10.23

\title{
The concept of "pandemic" in modern English-language political discourse
}

\section{Концепт «пандемія» в сучасному англомовному політичному дискурсі}

Received: October 10, 2021

Abstract

Real-life is closely linked to speech. How and what we communicate often speaks both about ourselves and about the conditions in which we find ourselves. The same applies to the situation around the coronavirus pandemic. One way or another, it influenced the way and the subject we talk about. In this article, we consider the measurement of speech changes under the influence of a pandemic on the example of the political discourse of English-speaking countries. Our goal was to find out how the coronavirus influenced political discourse and what specific examples can be used to demonstrate this. To carry out research, we used general and special scientific methods, in particular, content analysis, linguistic analysis. Among the sources, we have studied are scientific articles on the research topic, as well as materials of publications of the world's leading media on the research topic. As a result of this work, we concluded that the political discourse reflects the situation around the coronavirus in terms of the speaker and the goals he sets for himself. At the same time, for professional politicians, the pandemic has become a platform for a power struggle, so some of them openly manipulate information. One of the interesting areas of research is the means of communication in a crisis, in particular, the use of Internet memes to demonstrate their political position. This, as
Accepted: November 6, 2021

Written by:

Nataliia Shkvorchenko ${ }^{90}$ https://orcid.org/0000-0002-7146-7244

Viktoriia Hromovenko ${ }^{11}$ https://orcid.org/0000-0001-6706-3231

Yuliia Sharapanovska ${ }^{22}$ https://orcid.org/0000-0002-5397-2941

\footnotetext{
${ }^{90}$ Ph.D., Associate Professor of Romano-Germanic Philology and Methods of Teaching Foreign Languages, International Humanitarian University, Odesa, Ukraine.

${ }^{91}$ Doctor of Philosophy, Associate Professor of the Department of Foreign Languages of Professional Communication of the International Humanitarian University, Ukraine.

${ }^{92}$ Graduate student of the Department of Romano-Germanic Philology and methods of teaching foreign languages International Humanitarian University, Director of the Professional College of the International Humanities University, Odesa, Ukraine.
} 
well as coronaviral neologisms, need further study.

Keywords: pandemics, coronavirus, politics, discourse, political discourse.

\section{Introduction}

Coronavirus, like it or not, has become a real test of endurance and personal qualities for political leaders (Kahl \& Wright, 2021). It is in times of crisis that society needs quality leadership that knows the answers to difficult questions, has a plan, knows how to act, and in a global epidemic - how to save everyone. In this regard, quality communication between politicians and the public becomes even more important. Full and transparent information on the epidemic situation is a personal human right, linked to his or her right to an adequate standard of living and health care. However, in addition to the actual political leaders as political figures, there are also opinion leaders, experts, public figures, activists, famous people. They also participate in political discourse, as their statements may relate to public life, especially if it concerns the situation around the corona crisis, which has an impact on the vast majority of spheres of human life. Thus, it turns out that political discourse is structurally formed due to the addressees in the role of society, population, social groups, to which a message is addressed by the addressees, which are political actors, examples of which we mentioned above. Between these parties there is an interaction, the essence of which is to implement a communicative act, which is manifested in the exchange of information. Most often, this communication is carried out to inform, convey a message, but since it is a matter of political discourse, often the purpose of communication is a discussion to develop public consensus on current social, economic and other issues. For politicians, for example, the issue of having information about public opinion, in particular, about their activities and personalities, is essential. Politicians seek to know their audience and communicate successfully with it, clearly and effectively communicate their messages to the target audience. From this point of view, the function of political discourse is a power struggle, because in the process of communication there is a struggle for the consciousness and commitment of social groups, which aims to expand its influence, spread authority, etc. As we can see, the functions performed by political discourse are not limited to one thing, although in social disciplines there кризи, зокрема, використання інтернет-мемів для демонстрації своєї політичної позиції. Це, a також коронавірусні неологізми, потребують подальшого вивчення.

Ключові слова: пандемії, коронавірус, політика, дискурс, політичний дискурс.

has been a desire to reduce political discourse to the essence of manipulation and power struggle (van Dijk, 2008; Foucault, 2019).

We can say that the pandemic was an invasion of the real (French "reel") in the sense in which it was demonstrated in his works by Jacques Lacan before his 7th seminar (Eyers, 2012). This means that the crisis caused by the spread of coronavirus is a phenomenon that we cannot control. Their nature is available to us only indirectly - through the symbolic, which is realized in linguistic form. Another example is the interpretation of Lacan's Real by the Slovenian philosopher Slavoj Žižek, according to which Lacan's Real exists in three modalities: the real Real itself, symbolic and imaginary (Daly, 2004). According to our comparison, the coronavirus pandemic here acts as a horrible and uncontrollable real Real.

The pandemic existed among other linguistic units before the beginning of the situation around COVID-19. To better illustrate this, imagine what is now called a "text cloud," in which the most commonly used terms in discourse are the largest (Kaser \& Lemire, 2007; Heimerl, Lohmann, Lange, \& Ertl, 2014). Accordingly, to simplify the procedure, we can say that since the previous global epidemic, the concept we are analyzing has temporarily ceased to exist in political discourse, and the field of view of political communication has become dominated by other pressing issues. However, as the situation spiraled out of control, the pandemic did not simply return to political discourse but now occupies a leading position among the set of concepts used in it.

To further develop this idea, note that the "text cloud" of political discourse can be seen as a book, and then the pandemic can be seen as a "book within a book" because it has a cloud of words around it, that is, related concepts, already characteristic of pandemic discourse, if we undertake to consider it as a separate phenomenon. This means that we can distinguish in a pandemic discourse a set of interconnected concepts that are used with varying degrees of intensity, and present them in the form of 


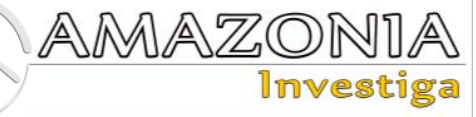

infographics, presented as a "text cloud". For this purpose, used words such as pronouns and conjunctions, as well as specific words, are removed from the context search, leaving space only for meaningful nouns, adjectives, verbs (Mehta, 2006). Of course, we are mainly interested in nouns, because they are primarily used with a nominative function concerning concepts. In this aspect, now around the pandemic, except COVID, the most common concepts are: masks, social distancing, contact tracing, personal protective equipment, quarantine, flatten the curve, virtual learning, outbreak, disease, contagious, infectious, lockdown, essential workers, vaccination, coronacrisis, index case, restrictions, COVIDcertificates, passes / passes, number of victims / infections / sick / dead / those who recovered, anti-record, etc. (Merriam-Webster, 2020). Therefore, from a linguistic point of view, it is necessary to pay attention to how real-world phenomena such as coronavirus affect word formation and speech use, how real phenomena affect language, change it.

Earlier, we have given examples of words that refer to specific vocabularies, such as medical, and even more narrowly - epidemiological. They significantly increased their representation in political discourse during the COVID-19 pandemic.

Carter (1999) pointed out in his work that inventing new words serves not only as entertainment, but also serves practical purposes, for example, in order to get familiar with the situation, to adapt, to overcome hurdles, etc. Zoom, covidiot, superspreader, anti-maskers, doomscrolling are just some of the examples of such adaptation of spoken language to new phenomena (Seattle Times, 2021).

Phrases such as "the new normal", "unprecedented times", "now more than ever" (Editor Group, 2021) have moved to the category of clichés. Steel constructions such as "to $\mathrm{X}$ or not to $\mathrm{X}$ ", "the mother of all $\mathrm{X}$ ", "X is the new $Y^{\prime}$, have become used in discourse to quickly and clearly identify the problem associated with the coronavirus (Couto, 2021). A study conducted by Bergs (2018) states that this category of clichés belongs to the so-called "Snowclones", which are a way to reproduce creativity according to the given parameters. The author calls this approach fixed creativity. In contrast, extended creativity goes beyond the rules of word / phrases construction.
In this article, we aim to consider the general theoretical impact of the pandemic as a concept on political discourse in English-speaking countries using specific examples of political life.

\section{Theoretical Framework or Literature Review}

The coronavirus pandemic has been the subject of numerous humanities studies. Attention is drawn to the threat of radical change in almost all spheres of life. For example, the narrative has become widespread, according to which "the world will never be the same / as it was before" uses phrases like "the new normal", "new world order", which has already become a cliché not only in political discourse (Kelly, 2021). For example, such judgments can be found in the publication Ilyas (2020). According to her, coronavirus infection puts both liberal and authoritarian regimes in the same conditions, but their means of combating the crisis are not the same, so it is unknown who will be the winner earlier than others, but we can say for sure that it will not be the same.

Former US Secretary of State Kissinger (2020) in his publication for the Wall Street Journal points to the importance of US initiative in combating the global political and humanitarian crisis. In his view, US political leadership should be manifested on three fronts: global, economic recovery, and the preservation of liberal values. In the title of the article, he uses the phrase "pandemic will forever alter the world order".

This begs the question, has the world really changed forever because of the coronavirus? What does this actually mean? Isn't that an exaggeration? Is it possible to adequately assess the consequences of the crisis directly during the crisis? And hasn't this narrative become a kind of stereotype, a cliché, behind which there is nothing in the sense of a thorough study, an objective point of view, and not the reduplication of a loud statement? For example, Kozhukhov (2020) in his publication uses just such criticism and notes that similar crises have already occurred in the history of mankind and its overall course was slightly affected, because people did not stop going to church, growing food, arguing, fighting, etc. As specific examples, he cites the pandemic of the H1N1 virus and influenza.

A study by Pickup, Stecula, \& Van Der Linden (2020) found that the reaction of political elites to the pandemic differed between the United States and Canada. For example, in the United States, the first reaction of the previous 
administration was skepticism and denial about the epidemic (Abutaleb et al., 2020; Stecula, 2020). In Canada, political elites have shown solidarity (Merkeley et al., 2020; Owen, 2020).

A study by Cornelson \& Miloucheva (2020) demonstrates that political polarization negatively affects compliance with anti-epidemic norms. Gadarian, Goodman, \& Pepinsky (2020) support this view.

A study by Motta, Stecula, \& Farhart (2020) found that there is a correlation between the use of untested resources and those who use such information. The authors conclude that such a correlation exists concerning supporters of extreme right-wing ideologies. Osmundsen et al. (2021) develop this view and show that this phenomenon lies in the emotional attitudes of those who spread misinformation and their political preferences. They use this to assert themselves and their ideology in discourse by humiliating their opponents.

Stecula \& Pickup (2021) demonstrate that belief in populist slogans can lead to negative consequences, in particular, a person's maladaptation to counter the spread of coronavirus due to distrust of government, official institutions, belief in conspiracy theories, distrust of scientists. Consumption of conservative-oriented, far-right-oriented media reinforces these trends.

\section{Methodology}

To carry out the study, we used general and special scientific methods.

We applied the method of analysis to show how political discourse is arranged at the present stage of research. With this, it was shown that it can consist not only of professional politicians at one end of communication but also users of social networks can be active participants in communication within the political discourse, as well as actors in political discourse. In particular, in the materials devoted to the polarization of society by the criterion of political beliefs, under the influence of the coronavirus epidemic, this is demonstrated in more detail.

The use of discourse analysis has been useful to demonstrate the role of power relations in shaping political discourse. In this regard, it should be noted that the political discourse is largely based on the relationship of subordination, where the participants in communication seek to assert themselves through their narrative. Thus, political discourse in this form is a power struggle.

We used content analysis to identify the most popular words and phrases, expressions that are closely associated with the concept of pandemic and coronavirus. We give examples of the use of these words in everyday and political discourse, mostly through references to official sources and through the use of phrases and phrases that came from the lips of politicians themselves.

We used linguistic analysis to look at how psychological, social, and speech factors are related, and how this affects political discourse and everyday discourse, the speech of people, and social groups.

\section{Results and Discussion}

According to Steblyna (2020), during situations characterized by a high degree of uncertainty and social tension, elites come to the fore. This is due to the focus of broad social groups on the figure of the leader, but not only because of their helplessness in the face of a global problem (this is not entirely true, as local people can effectively combat coronavirus infection (See, for example, Tiratelli \& Kaye (2020), but also simple to navigate the situation, as official authority figures are the mouthpieces of the primary link in obtaining official information, in contrast to everyday discourse, which in one way or another contains dubious data, such as rumors about the coronavirus. In her study, Steblyna (2020) points out that the problems of political discourse in a pandemic are related to the fact that the scope of the coronavirus topic becomes so large that it displaces everyone else. Thus, there may be a false impression that there are no other problems. Related to this is the other side, which is the negative psychological impact of a constant flow of the same type of negative messages. For example, doomscrolling during the first wave of the coronavirus meant a compulsive review of a news feed that consisted exclusively of the topic of the coronavirus, death statistics, emergencies, and so on. Monitoring and avoiding (Ytre-Arne $\&$ Moe, 2021) were alternative ways of consuming news. In addition, the predominance of isolationist tendencies becomes characteristic of political discourse in a pandemic (Ilyas, 2020). According to the Pew Research Center, Americans have assessed the impact of the coronavirus on the country's political life as almost entirely negative (Kessel, Baronavski, Scheller, \& Smith, 2021). In support, respondents noted that the corona crisis divides and radicalizes people, and political parties are a 


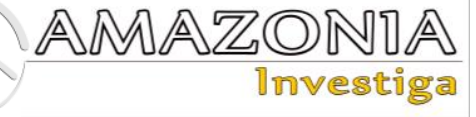

clear manifestation of this, as they fight hard for power in conditions where the consolidation of society is needed. $26 \%$ of respondents criticized the slow reaction of the authorities to the spread of the disease, pointing to the degradation of government institutions. In addition, they complained about the requirement to wear masks, as they considered it a violation of personal liberty. Republicans mentioned negative change more often than Democrats (31\% vs. $21 \%$ ). In contrast, other residents said that the coronavirus forced them and their neighbors to take more care of each other, strengthening family ties. Their answers also manifested themselves in the form of objections from other respondents. For example, the authorities are acting effectively, and that another person's refusal to wear a mask violates their right to security. However, researchers who surveyed and measured US public opinion on the subject point out that the share of positive responses is negligible compared to criticism. This significantly affects the ability to objectively measure positive feedback, which is why they are presented as single and insignificant in the study.

The electoral process has been threatened by the coronavirus pandemic (Heathershaw \& Trechard, 2020). On social media, users have expressed concern about the legitimacy of elections that will be attended by fewer people or that are constantly being postponed (Lerer \& Epstein, 2020). Attention was drawn to the risks to democracy posed by the coronavirus (Garrison, 2020). These and other things are pointed out in their study by Landman \& Splendore (2020). In their view, the postponement of elections is clearly a bad phenomenon for democracy, as it triggers negative scenarios, provokes social discontent, etc.

An interesting example of how violent the political discourse can become during a pandemic is the statement attributed to the Prime Minister of the United Kingdom Boris Johnson about the use of herd immunity (Krishna, 2020). In his speech on This Morning on March, 5th, he used the phrase "to take it in the chin", which caused a flurry of criticism. However, the phrase was taken out of context, because Johnson used this statement to describe only one point of view on the development of coronavirus resistance.

The pandemic in political discourse is a territory of the struggle for power and the subject of discussions, mutual accusations of insufficient effectiveness of countermeasures. For example, a typical scheme is the opposition's accusation by the ruling party that the government is not doing enough to fight the coronavirus (Stecula, 2020). An alternative scenario is a consolidation of society and its oppositions, which are represented by political forces. It is noteworthy that, in practice, we can see how those who criticize the government will behave concerning the pandemic only when it changes. For example, incumbent President Joe Biden overturned his predecessor's decision regarding health care organizations such as the CDC and WHO (Brewster, 2021; Griffin, 2021). The aim was to demonstrate commitment to the global pandemic effort (concerning the WHO), the CDC's efforts to control the coronavirus in the United States and to show respect for the authority of the scientific and medical community. In contrast, the previous administration often criticized official institutions, openly doubting the natural origin of the coronavirus (Farhi, 2020).

However, it is difficult to say that this is a situation that is due to the spread of the coronavirus. As in most cases, the pandemic in this aspect served as a catalyst for previous processes. For example, according to a study by Guess, Nagler, \& Tucker (2019), proponents of conservative ideologies in the United States more often than moderate and liberal voters disseminated material citing questionable sources. In addition, there was a significant correlation between the spread of so-called "Fake news" and the age of the addressees. For example, users of social networks over the age of 65 were seven times more likely to cite questionable sources than the youngest age group of recipients. In another study by Osmundsen et al. (2021), substantiates the point of view, according to which such behavior of social network users indicates not so much their ignorance, but the desire by any means to legitimize their point of view and "destroy" their opponents, an emotional indicator of the attitude to which, of course, is hatred, contempt, irritability, condemnation. It is no coincidence that to humiliate opponents, such individuals are willing to disseminate knowingly false information, even if they are aware that it has been collected and disseminated dubiously. Researchers who have conducted such analysis show that the cause of such behavior is party polarization, which is based on psychological motives. This does not prevent individuals who use references to questionable sources to justify their position and humiliate opponents from disseminating information from verified and traditional sources that enjoy authority and trust, even from an academic point of view. 
As we can see, the concept of a pandemic in political discourse applies in the same way, because to justify their political position, for example, supporters of radical personal freedom may use dubious news sources that deny the effectiveness of restrictive measures, and supporters of such measures will refer to scientific research and recommendations from reputable scientific and medical institutions such as the aforementioned WHO and CDC. From a philosophical point of view, this can be reformulated in such a way that from the point of view of an outside observer, it looks not so much a search for objective truth as a justification of one's identity, i.e. legitimization of one's narrative in discourse, and thus self-affirmation through power. in the political struggle, which is manifested in political debates and discussions.

Among the socio-political phenomena that existed before the pandemic, indifference to political processes stands out. This is a worrying characteristic of the global scale, not just of an individual country. For example, in 2017, the Reuters Institute released a report stating that $29 \%$ of the population does not follow or knowingly avoids receiving political news (Newman, 2017). Another study found that $44 \%$ of respondents in 38 countries did not believe that the political news provided to them by the media was biased. Another source notes that such events create a sense of powerlessness among social groups in the face of political challenges, as such people do not feel fully involved in the process and cannot influence it because their efforts are futile and "nothing changes" - a common position among people desperate in politics (Gans, 2004). Some experts, in particular the Ukrainian philosopher Andriy Baumeister, criticize modern political discourse in terms of the fact that it has become an appeal to buyers in the market, namely - "politics has become a supermarket" (UKRLIFE.TV, 2020). Such an accusation of "marketing" policy means that every citizen can find something for themselves in such a place, but the situation, in general, is not affected, although sellers in the meantime receive dividends from your purchases. Similar observations can be found in the work of other researchers (Iggers, 1999; Thompson, 2016).

An unobvious element of modern political discourse in social networks is the use of memes. This term most often refers to an image of a humorous nature, which was created according to a template and with an inscription on it (Shifman, 2014). Memes often contain references to a cultural source, and footage from movies, TV series, photos of politicians, celebrities, etc. is used as a template. Thus, in this aspect, we can say that the Internet image as a meme appeals to things that are clear to the recipient to be a clear message and evoke an emotional response. At first glance, this may seem like a phenomenon not worth researching. However, the exchange and dissemination of quality memes is relevant for young people, in particular those involved in social activism. Performing primarily an entertaining function in the mass consciousness, they unquestioningly convey information that is depicted as a joke or reference to another source, which is often part of mass culture.

There is a well-known point of view of Richard Dawkins (2014), according to which memes as part of the culture, or cultural units, can be depicted in terms of evolution. This means that they have such traits as reproduction, or reproduction (replication), variability, and undergo a process of selection or selection. To make this clear, it should be noted that the image as a meme is really first to be reproduced because it is multiplied and copied according to a particular pattern. In the future, it is subject to modification in terms of the purpose of creation, as well as in view of the specific situation, especially in relation to the environment or recipients to whom the message is directed in the form of a meme as an image. Thus, several factors affect how the modification of the meme image will take place, which is its variability. The selection of memes is manifested in the fact that unpopular memes are to be forgotten, and popular ones can always circulate in public space, replicating and changing (Distin, 2004).

A study by Italian scientists has shown that memes become more complex every year (Valensise, Serra, Galeazzi, et al., 2021). To do this, they analyzed 2 million images from the American imageboard Reddit, which were published during 2011-2020. Scientists have concluded that the complexity of such content doubles every six months, and the significant popularity of meme templates due to their initial success, so the image is not immediately found a response from the public, will not be able to gain popularity. At the same time, the peak popularity for any image begins to decline by 3-4 months.

According to de Saint Laurent, Glăveanu, \& Literat (2021), coronavirus political memes can be the subject of analysis. To do this, they use narrative analysis within the meme in terms of transactional and linguistic analysis. Thus, they single out the figures "Persecutor-Victim-HeroFool" and apply them to the most popular memes, which are considered as political narratives. As a 


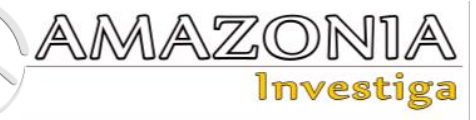

result of the study, they found that there are five main scenarios for this type of communication, most of which are criticisms of the incompetence of the government, which is expressed in humorous form.

\section{Conclusions}

A pandemic is indeed a litmus test for many phenomena. Regarding the political discourse of English-speaking countries, it showed the problems that existed before. For example, the lack of political leadership or its questionable quality, the polarization of society, the need to improve health care, strategic planning, rapid response, decentralization, involvement of local governments in active action, shortage of leaders, and degradation of elites - all this somehow came to the surface during the crisis.

It can be said that the political discourse of English-speaking countries is formed under the agenda and current challenges that arise in the social and economic spheres, and connection with the spread of the epidemic - in the field of health care. This can be traced to topics discussed at different times, such as the impact of the coronavirus on elections during the election period, criticism of the government's slow response to the crisis at the beginning, increasing political competition, and polarization of society as the crisis intensifies, etc.

Notable are studies on the correlation between political preferences and attitudes toward coronavirus. Proponents of far-right movements in this regard tend to show more disregard for quarantine restrictions, which in political discourse is manifested in the use of sources of questionable information to support their point of view. It is a matter of concern that such means of communication (manipulation) are also used by political officials. This is threatening in terms of the impact they can have on society by abusing their power and authority.

The phrases that are heard from politicians, in addition to the pandemic, differ in their evaluative color, which is most often aimed at consolidating society ("help us flatten the curve", "we are all in this together", "get vaccinated / a vaccine"). "Help us save lives"), however, skeptical, critical remarks may be made about the nature, origin, and reality of the coronavirus ("it is a hoax"). In this regard, we note that the socalled The "infodemia", which is characterized by the dissemination of large amounts of information, in particular dubious, unverified, untrue, misleading, is a side or concomitant effect of the spread of the coronavirus epidemic, and the scientific community must continue to participate in collective and global action against this.

\section{Bibliographic references}

Abutaleb, Y., Dawsey, J., Nakashima, E., \& Miller, G. (April 4, 2020). The U.S. Was Beset by Denial and Dysfunction as the Coronavirus Raged. The Washington Post. Recovered from https://www.washingtonpost.com/nationalsecurity/2020/04/04/coronavirusgovernment-dysfunction/?arc404=true

Bergs, A. (2018). Learn the Rules like a Pro, so you can Break them like an Artist (Picasso): Linguistic Aberrancy from a Constructional Perspective. Journal of English and American Studies, 66(3), 277-293. Recovered from https://doi.org/10.1515/zaa-2018-0025

Brewster, J. (January 24, 2021). CDC Director: Agency Was 'Muzzled' Under Trump. Forbes. Recovered from https://www.forbes.com/sites/jackbrewster/2 021/01/24/cdc-director-agency-wasmuzzled-under-trump/?sh=7a5787db6fed

Carter, R. (1999). Common language: corpus, creativity and cognition. Language and Literature, 8(3), 195-216. Recovered from https://doi.org/10.1177/09639470990080030 1

Cornelson, K., \& Miloucheva, B. (April 7, 2020). Political Polarization, Social Fragmentation, and Cooperation during a Pandemic. Working paper 663. Department of Economics. University of Toronto. Recovered from https://www.economics.utoronto.ca/public/w orkingPapers/tecipa-663.pdf

Couto, D.T. (September 13, 2021). The rise of COVID 'snowclones' - the mother of all linguistic phrases. The Conversation. Recovered from https://theconversation.com/the-rise-ofcovid-snowclones-the-mother-of-alllinguistic-phrases-167580

Daly, G. (2004). Slavoj Zizek: A Primer. Lacanian Ink. Lacan. Recovered from https://www.lacan.com/zizek-primer.htm\#1

Dawkins, R. (2014). The Selfish Gene. Princeton University Press.

De Saint Laurent, C., Glăveanu, V.P., \& Literat, I. (2021). Internet memes as partial stories: Identifying political narratives in coronavirus memes. Social Media+ Society, 7(1), 2056305121988932. Recovered from https://journals.sagepub.com/doi/pdf/10.117 7/2056305121988932 
Distin, K. (2004). The Selfish Meme. Cambridge University Press.

Editor Group. (2021). The three COVID clichés it's time to stop using. Recovered from https://www.editorgroup.com/blog/threecovid-cliches-its-time-to-stop-using/

Eyers, T. (2012). Lacan and the Concept of the "Real". Basingstoke: Palgrave Macmillan.

Farhi, P. (August 14, 2020). Two sites that amplify hoaxes given special treatment at Trump's briefings despite restrictions. The Washington Post. Recovered from https://www.washingtonpost.com/lifestyle/m edia/two-sites-that-amplify-hoaxes-givenspecial-treatment-at-trumps-briefingsdespite-restrictions/2020/08/14/8579032ede6e-11ea-809e-b8be57ba616e_story.html

Foucault, M. (2019). Power: the essential works of Michel Foucault, 1954-1984. Penguin UK.

Gadarian, S.K., Goodman, S.W., \& Pepinsky, T.B. (March 30, 2020). Partisanship, Health Behavior, and Policy Attitudes in the Early Stages of the COVID19 Pandemic. SSRN. Recovered from https://ssrn.com/abstract=3562796

Gans, H. (2004). Democracy and the News. New York: Oxford University Press

Garrison, J. (March 17, 2020). As coronavirus pandemic delays 2020 primaries, is it time to worry about the November election? USA Today. Recovered from https://www.usatoday.com/story/news/politi cs/elections/2020/03/17/coronaviruspandemic-delays-primaries-time-worry2020-november-election/5057930002/

Griffin, R. (2021). U.S. Moves Pandemic Data Tracking to CDC, Reversing Trump. Bloomberg. $\quad$ Recovered from https://www.bloomberg.com/news/articles/2 021-10-14/u-s-shifting-pandemic-trackingback-to-cdc-after-trump-move

Guess, A., Nagler, J., \& Tucker, J. (2019). Less than you think: Prevalence and predictors of fake news dissemination on Facebook. Science Advances, 5(1), eaau4586. Recovered from https://www.science.org/doi/pdf/10.1126/sci adv.aau4586

Heathershaw, J., \& Trechard, J. (2020). How to Hold an Election During a Pandemic. Pendemipolitics. Recovered from https://pandemipolitics.net/how-to-hold-anelection-during-a-pandemic/

Heimerl, F., Lohmann, S., Lange, S., \& Ertl, T. (2014). Word cloud explorer: Text analytics based on word clouds. In 2014 47th Hawaii International Conference on System Sciences (pp. 1833-1842). IEEE.
Iggers, J. (1999). Good News, Bad News. Journalism. Ethics and the Public Interest. Boulder, Colo.: Westview Press.

Ilyas, A. (April 24, 2020). Covid-19 Pandemic: Emergence of a New Geopolitical Perspective. Sustainable Development Policy Institute. Recovered from http://hdl.handle.net/11540/11906

Kahl, C., \& Wright, T. (2021). Aftershocks: Pandemic Politics and the End of the Old International Order. St. Martin's Press. Recovered from https://www.amazon.com/AftershocksPandemic-Politics-InternationalOrder/dp/1250275741

Kaser, O., \& Lemire, D. (2007). Tag-cloud drawing: Algorithms for cloud visualization. arXiv preprint cs/0703109. Recovered from https://arxiv.org/pdf/cs/0703109.pdf

Kelly, L. (2021). Pandemic clichés and how to avoid them. Readable. Recovered from https://readable.com/blog/pandemic-clichesand-how-to-avoid-them/

Kessel, P., Baronavski, C., Scheller, A., \& Smith, A. (March 5, 2021). In Their Own Words, Americans Describe the Struggles and Silver Linings of the COVID-19 Pandemic. Pew Research Center. Recovered from

https://www.pewresearch.org/2021/03/05/intheir-own-words-americans-describe-thestruggles-and-silver-linings-of-the-covid-19pandemic/

Kissinger, H. (2020). The coronavirus pandemic will forever alter the world order. The Wall Street Journal. WSJ Opinion. Recovered from https://www.wsj.com/articles/thecoronavirus-pandemic-will-forever-alter-theworld-order-11585953005

Kozhukhov, M. (2020). The world will remain the same. Snob.ru. Recovered from https://snob.ru/profile/28509/blog/166147

Krishna, R. (2020). Here is the transcript of what Boris Johnson said on this morning about the new coronavirus. Full Fact. Recovered from https://fullfact.org/health/boris-johnsoncoronavirus-this-morning/

Landman, T., \& Splendore, L. (2020). Pandemic democracy: elections and COVID-19. Journal of Risk Research, 23(7-8), 1060-1066. Recovered from https://doi.org/10.1080/13669877.2020.1765 003

Lerer, L., \& Epstein, R.J. (2020). How the Coronavirus Changed the 2020 Campaign. The New York Times. Recovered from https://www.nytimes.com/2020/03/12/us/pol itics/coronavirus-2020-campaign.html 


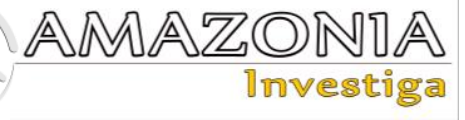

Mehta, C. (2006). US Presidential Speeches Tag Cloud. Chirag Mehta. Recovered from https://chir.ag/projects/preztags/

Merkeley, E., Bridgman, A., Loewen, P.J., Owen, T., Ruths, D., \& Zhilin, O. (2020). A rare moment of cross-partisan consensus: Elite and public response to the COVID-19 pandemic in Canada. Canadian Journal of Political Science/Revue canadienne de science politique, 53(2), 311-318. Recovered from

https://doi.org/10.1017/S0008423920000311

Merriam-Webster. (2020). A Guide to Coronavirus-Related Words. Recovered from https://www.merriam-webster.com/wordsat-play/coronavirus-words-guide/covid-19

Motta, M., Stecula, D., \& Farhart, C. (2020). How right-leaning media coverage of COVID-19 facilitated the spread of misinformation in the early stages of the pandemic in the US. Canadian Journal of Political Science/Revue canadienne de science politique, 53(2), 335-342. Recovered from https://doi.org/10.1017/S0008423920000396

Newman, N. (2017). Reuters Institute Digital News Report 2017. Oxford: Reuters Institute for the Study of Journalism.

Osmundsen, M., Bor, A., Vahlstrup, P., Bechmann, A., \& Petersen, M. (2021). Partisan Polarization Is the Primary Psychological Motivation behind Political Fake News Sharing on Twitter. American Political Science Review, 115(3), 999-1015. doi: 10.1017/S0003055421000290

Owen, L.H. (2020). Older people and Republicans are most likely to share Covid19 stories from fake news sites on Twitter. NiemanLab. Recovered from https://www.niemanlab.org/2020/10/olderpeople-and-republicans-are-most-likely-toshare-covid-19-stories-from-fake-newssites-on-twitter/

Pickup, M., Stecula, D., \& Van Der Linden, C. (2020). Novel coronavirus, old partisanship: COVID-19 attitudes and behaviours in the United States and Canada. Canadian Journal of Political Science/Revue canadienne de science politique, 53(2), 357-364. Recovered from https://doi.org/10.1017/S0008423920000463

Seattle Times. (2021). From 'anti-masker' to 'Zooming': Words and phrases that have become part of our COVID-19 vocabulary. Recovered from https://www.seattletimes.com/life/from-antimasker-to-zooming-words-and-phrases-that- have-become-part-of-our-covid-19vocabulary/

Shifman, L. (2014). Memes. MIT Press.

Steblyna, N.O. (2020). COVID-19 and the transformation of Ukraine's digital political discourse in 2020. Political Life, 2, 103-110. Recovered from https://jpl.donnu.edu.ua/article/view/8850

Stecula, D. (2020). What do we know about misinformation during the coronavirus outbreak? Mischiefs of Faction. Recovered from

https://www.mischiefsoffaction.com/post/wh at-do-we-know-about-misinformationduring-the-coronavirus-outbreak

Stecula, D.., \& Pickup, M. (2021). How populism and conservative media fuel conspiracy beliefs about COVID-19 and what it means for COVID-19 behaviors. Research \& Politics, 8(1), 2053168021993979. Recovered from https://doi.org/10.1177\%2F20531680219939 79

Thompson, M. (2016). Enough Said: What's Gone Wrong with the Language of Politics? New York: St. Martin's Press. Recovered from https://www.amazon.com/EnoughSaid-Whats-Language-

Politics/dp/1250059577

Tiratelli, L., \& Kaye, S. (2020). Communities vs. Coronavirus. The Rise of Mutual Aid. New Local Government Network. New Local. Recovered from http://newlocal.org.uk/wpcontent/uploads/2020/12/Communities-vsCoronavirus_New-Local.pdf

UKRLIFE.TV. (July 1, 2020). Politics has become a supermarket - Andrey Baumeister [Video]. YouTube. Recovered from https://www.youtube.com/watch?v=L_5tOY jIXfg

Valensise, C.M., Serra, A., Galeazzi, A. et al. (2021). Entropy and complexity unveil the landscape of memes evolution. Scientific Reports, 11, 20-22. Recovered from https://doi.org/10.1038/s41598-021-99468-6

Van Dijk, T.A. (2008). Discourse and power. New York: Palgrave Macmillan. Recovered from

https://www.worldcat.org/title/discourseand-power/oclc/244660683

Ytre-Arne, B., \& Moe, H. (2021). Doomscrolling, Monitoring and Avoiding: News Use in COVID-19 Pandemic Lockdown. Journalism Studies, 1, 1-17. Recovered from https://doi.org/10.1080/1461670X.2021.195 2475 